\title{
Integral Membrane Protein GPR180
}

National Cancer Institute

\section{Source}

National Cancer Institute. Integral Membrane Protein GPR180. NCI Thesaurus. Code

C153055.

Integral membrane protein GPR180 (440 aa, $\sim 49 \mathrm{kDa}$ ) is encoded by the human GPR180 gene. This protein may be involved in $\mathrm{G}$ protein-receptor-mediated signaling and remodeling of the vasculature. 